\title{
DOGMELE ŞI VALORIFICAREA LOR ÎN VIAȚA CREDINCIOŞILOR ORTODOCŞI DIN PERSPECTIVA GÂNDIRII PĂRINTELUI DOMETIE DE LA RÂMET,
}

\author{
Stelian Manolache
}

\begin{abstract}
The holy Synode of the Roumanian Orthodox Church has declared year 2015 to be the hommage year for the Nowadays Parochy and Monastery Mission as well as the commemorative year of Saint John Chrysostome and the great soul pastors of the eparchies. Under the impact of those valoric steps, the diocesan centers and the faculties of theology across these, have planned several scientific sessions, taking into account the concrete realities of current cultural and social context, as well as the events that have marked the history of our Church. Thus, from various theological points of view, the social-pastoral and moral mission of the Church started to emerge, rising from the sanctifying work of the divine Grace, reflected in the teaching that our ancient Church received from our Savior Jesus Christ and faithfully passed on by His Holy Apostles, the Church Fathers and Patristic writers to this day, observing our Savior's commandment, "Go, teach all the nations, baptizing them in the name of the Father and the Son and the Holy Spirit, teaching them to keep all my commandments. I am with you until the end of time" (Matthew 28, 19-20).

An important role in this process of passing on the Christian teaching and turning the living of it into fact, preached by Jesus Christ, will be fulfilled by the descent of the Holy Spirit upon the Apostles at the Pentecost, a process that would lead, in time, not only to the enrichment of a Christian's personal life in observance of the commandments of God within a world dominated by the sin of disobedience, but will also be a renewing step into spirituality within and through the Church, which will take the faithful to the light of human deification (theosis) by experiencing the eternity in History: "After thy rise from thy grave, O Christ, and by divine elevation to heavenly heights, you sent your glory to those who see God, merciful, renewing the righteous Spirit to thy disciples. To do this, Savior, like a melodious harp, you made known to all, mysteriously, with the divine bow, Your words and order" (Sedealna after Polyeleos, Matins of Pentecost).
\end{abstract}

In this context, the Faculty of Orthodox Theology "Simion Ştefan" of 
Alba-Iulia, has suggested a generous theme of theological approach by means of the symposium The missionary Ethos of the Church in the Postmodern Age, in respect with which we hereby submit a homage paper about the dimension of the valorization of the dogma in the Orthodox believer's lives according to the thought of Dometie Manolache, Father Abbot of the Monastery Râmeț, of this Archdiocese.

Keywords: mission, dogma, faith, God's Grace, the Holy Liturgy, Holy Sacraments, religious services, orthodox spirituality.

\section{Preliminarii}

Mânăstirea Râmeț a fost, de-a lungul veacurilor, prin duhovnicii săi, un adevărat far al spiritualității ortodoxe româneşti. Acesta va lumina de-a lungul istoriei frământate a neamului românesc din Transilvania, prin nume precum cele ale arhiepiscopului Ghelasie (sec. al XIV-lea) sau ale părintelui Dometie de la Râmeț (1924-1975), misiunea lor social-pastorală şi morală, ce vor fi înscrise în Patericul duhovniciei veşnice a Bisericii strămoşeşti. În ogorul Domnului, părintele Dometie a fost o personalitate aparte, îmbogăţind, prin predica şi sfatul duhovnicesc, viața spirituală şi practică a credincioşilor pornind de la cele două arme ale păstorului autentic, rugăciunea şi postul. Cele două arme, prin acțiunea lor, se vor concretiza, în timp, prin îmbogățirea vieții duhovniceşti, cât şi în viziunea reformatoare administrativă, asupra mânăstirii Râmeț, pe care părintele a (re)zidit-o din temelii, alături de monahia stavroforă Ierusalima Ghibu şi întreaga obşte monahală, precum şi a conducerii parohiilor - Valea Uzii, Pleaşa, Olteni -, pe care le-a păstorit cu adâncă smerenie, dar şi eficacitate duhovnicească. Această imbogățire spiritual-practică, s-a datorat faptului că părintele Dometie a pus, în centrul misiunii sale, induhovnicirea spirituală şi practică a cu-mine-cării euharistice zilnice cu Trupul şi Sângele Mântuitorului Iisus Hristos ${ }^{1}$, a

\footnotetext{
${ }^{1}$ Stelian Manolache, Jertfa euharistică a Bisericii oglindită în viața pilduitormărturisitoare a părintelui Dometie de la Râmeț, în „Eucharist and Martyrdom
} 
comunității credincioşilor mocani, şi nu numai, spre dobândirea unei noi vieți creştine şi a mântuirii. Nu întâmplător, această activitate pastorală şi misionară va fi pusă sub semnul promovării şi valorificării spirituale a moştenirii culturale româneşti ortodoxe, concretizate prin răspunsul său prompt la solicitările credincioşilor, al catehizării tuturor categoriilor de oameni, precum şi al îngrijirii persoanelor bolnave, ajutorării copiilor săraci şi orfani, a famililor tinere aflate în dificultăți financiare, răspuns imbinat cu o solidă lucrare/activitate administrativă ce va vorbi, peste veacuri, inclusiv, prin proiectul zidirii catedralei Munților Apuseni, proiect definitivat de întâia ucenică a sa, stareța mânăstirii Râmeț, Ierusalima Ghibu. Ca ucenic al părintelui Arsenie Boca, părintele Dometie - omul casei lui Dumnezeu - a dus mai departe învățătura scripturistică şi tradiția marelui duhovnic al Ardealului, moştenită, la rândul lui, de la marii duhovnici ai Athosului, el păstrând acest testament prin echilibrul permanent între activitatea administrativă şi spirituală, adevărată cale domnească spre sporirea lucrării harului dumnezeiesc în viața practică a credincioşilor. S-a reuşit acest lucru, deoarece, pentru părintele Dometie, la loc de cinste s-a aflat Adevărul propovăduit al Mântuitorului nostru Iisus Hristos, oglindit în valorificarea vieții dogmelor, transpuse în viața practică de zi cu zi a credincioşilor (Ioan 14,6). Pentru a spori în această lucrare harică a Sfântului Duh în lume şi pentru lume, la sfatul bunului său prieten şi frate de călugărie, Antonie Plămădeală ${ }^{2}$, fostul Mitropolit al Ardealului, părintele Dometie, ca şef de promoție la Facultatea de Teologie din Bucureşti, se va înscrie, în anul 1974, la cursurile de doctorat în teologie - secția sistematică - , avându-l ca îndrumător pe părintele profesor Dumitru Stăniloae. Acesta 1-a primit cu drag la cursurile sale de doctorat, simpatizându-l încă de când era student, pentru frumusețea şi dăruirea jertfelnică a sufletului său în ascultarea de mai

from the Ancient Catacombs to the Communist Prisons, 6-8 mai 2014", vol. 2, Alba-Iulia, Edit. Reîntregirea, 2014.

${ }^{2}$ Lumină Lină, Părintele Dometie, Cuvânt înainte IPS Antonie, Mitropolitul Ardealului , Edit. Ararat, Bulevardul Carol I, nr. 43, Bucureşti, pp. 8-12 
marii Bisericii şi de profesorii de teologie din Bucureşti, între cei doi stabilindu-se o relație intelectuală şi spirituală excepțională de-a lungul întregii lor vieți. Părintele Stăniloaie îl va numi, nu întâmplător, admirativ, pe părintele Dometie, după părintele Arsenie Boca, cucuzelul Ortodoxiei, o adevărată ,pildă credincioşilor cu cuvântul, cu purtarea, cu dragostea, cu duhul, cu curăția" (I Timotei 4, 12). În anul 1975, la cursurile de doctorat, părintele Dometie îşi va publica, în premieră, în Revista „Studii Teologice”, numărul 3-4 din martie-aprilie 1975, o lucrare eveniment care va reverbera prin actualitatea sa formativ-creştină până în zilele noastre, în zorii postmodernității. Ea se intitula Dogmele şi valorificarea lor în viața credincioşilor ortodocşi.

\section{Câteva considerații generale asupra lucrării}

Observator fin în depistarea şi scoaterea în evidență a adevărului creştin, lucrarea porneşte de la abordarea critică a mişcărilor politico-religioase din Occident, pe care le va condamna pentru dezrădăcinarea fondului autentic de trăire creştină $\breve{a}^{3}$. În subtext, părintele Dometie milita, apologetic, pentru repunerea dogmei la locul ce i se cuvine, în acțiunea pedagogico-dogmatică a mântuirii, ce are loc prin şi în Unitatea Bisericii întemeiate de Mântuitorul Iisus Hristos. Scrisă într-o perioadă de convulsii politico-religioase dominate de mişcările neo-penticotise occidentale şi a mişcărilor studențeşti din Franța anului 1968, mişcări ce încurajau trăirile emoțiilor subiective ${ }^{4}$, dar şi a perioadei de apogeu a propovăduirii comuniste, ce contesta spiritualitatea Bisericii prin viziunea materialist-dialectică, lucrarea abordează problema delicată a mântuirii subiective pornind de la necesitatea şi valorificarea dogmei văzută ca adevăr fundamental trăit al Bisericii, contra-alternativă viabilă atât la punctul de vedere materialist-

3 Drd. Arhim. Dometie Manolache, Dogmele şi valorificarea lor în viața credincioşilor ortodocşi, în „Studii Teologice”, nr. 3-4, martie-aprilie 1975, p. 232.

${ }^{4}$ Ibidem. 
reducționist al omului nou comunist, cât şi al mişcărilor formaliste de trezire spirituală subiectivă din Occident ${ }^{5}$. Lucrarea a fost structurată în două părți, ce cuprind mai multe subcapitole. In prima parte, lucrarea are un caracter spiritual dogmatic, părintele Dometie abordând: A. Mişcările harismatice din Occident, semn al trebuinței creştinului de azi după trăirea dogmelor; B. Dogmă şi trăire în creştinismul Răsăritean şi cel Occidental; C. Nevoia naturală a credinciosului de a pătrunde adânc Adevărul Revelat, atât sub aspectul cunoaşterii cât şi al trăirii lui. In partea a doua, părintele Dometie abordează partea practică social-misionară şi liturgică a dogmei pornind de la $\mathrm{D}$. Mijloacele de valorificare şi de trăire efectivă a dogmelor în viața credincioşilor ortodocşi prin: 1. comuniunea credincioşilor şi participarea la Sfânta Liturghie, Sfintele Taine şi ierurgii, prin cântări şi citiri din scrierile filocalice, prin rugăciunea de obşte şi particulară. Lucrarea se încheie cu un scurt subcapitol de Concluzii. Pentru susţinerea şi demonstrarea punctului său de vedere, părintele Dometie va porni, în demersul său, de la Sfânta Scriptură şi Sfânta Tradiție, de la Sfinții Părinți până la marii profesori de teologie ai timpului său ${ }^{6}$.

${ }^{5}$ Ibidem, p. 233.

${ }^{6}$ Sfânta Scriptură, IBMBOR, Omilia VIII a Sf. Ioan Gură de Aur, P.G. XLVIII, 769; Pr. Prof. Dumitru Stăniloae, Ortodoxia în fața unor fenomene actuale din creştinismul apusean, în „Ortodoxia”, nr 2, 1974, pp. 339-340; Idem, Chipul lui Hristos în Biserica răsăriteană: Iisus Hristos Darul şi Cuvântul Suprem al lui Dumnezeu, în „Ortodoxia”, nr. 1, 1973, p. 9; Idem, Spiritualizarea structurilor Bisericeşti în epoca actuală şi cauzele ei, în „Ortodoxia”, 1972, nr. 4, pp. 521-522; Dr. Antonie Plămădeală, episcop vicarpatriarhal, Hans Kung şi declarația Mysterium Ecclesiae, Bucureşti, 1974, p. 41; Nicolae, Mitropolitul Ardealului, Despre unele caracteristici ale moralei catolice, în „Studii de teologie morală”, Sibiu, 1969, p. 199; Prof. Nicolae Chițescu, Dogma şi viața creştină, în „Studii teologice”, nr. 1-2, 1954, p.47; Profesor Constantin C. Pavel, Preocupări actuale în domeniul teologiei morale creşine, în „Studii Teologice”, nr. 3-4, 1973, p. 77; Pr. Prof Mihai Bulacu, Cunoaşterea lui Dumnezeu prin Ortodoxie, în „Glasul Bisericii”, nr.9-10, 1973, p. 1054. 


\section{Câteva considerații particulare asupra perspectivei misionar- dogmatice a lucrării}

3. 1. Mişcările harismatice, simptom al crizei spirituale din Occident, dar şi semn al trebuinţei creştinului după trăirea spirituală a dogmelor

Lucrarea începe prin prezentarea crizei spirituale din lumea creştină Occidentală, ce va reverbera până în zorii postmodernității. Despre această criză părintele Dometie scria profetic, că Biserica Ortodoxă ,trebuie nu numai să se pregătească pentru a fi gata să dialogheze polemic, cu noile forme false ale credinței, dar şi să le răspundă adecvat pornind de la tezaurul ei de credință nealterat" Dialogul va trebui să pornească în duhul dragostei față de aproapele, de la Adevărul dumnezeiesc al iubirii Sfintei Treimi ce, prin Fiul Său Întrupat, a dus la „restabilirea raportului de iubire între ființa noastră umană şi Dumnezeu, între noi şi semenii noştri" " . Odată cu apariția Bisericii văzute la sărbătoarea Cincizecimii, acest Adevăr va lua forma expresiei dogmatice, care este ,în acelaşi timp realitate, dar şi afectivitate" ${ }^{9}$. Dogmele constituie, după părintele Dometie, „osatura vieții bisericeşt $\mathrm{i}^{10}, \ldots$ expresia unor realităţi divine care ne întâmpină şi care intră în relație cu toți cei ce le acceptă in credință" ${ }^{11}$. În Ortodoxie aceasta înseamnă ,dreaptă-credință, cât şi dreaptă trăire", ea cerând de la credincioşii Bisericii ei să le învețe şi să le respecte pe amândouă, deoarece orice deviere de la dreapta invățătură va duce, implicit, şi la devierea dreptei trăiri" ${ }^{12}$.

\footnotetext{
${ }^{7}$ Drd. Arhim. Dometie Manolache, art. cit., p. 232.

${ }^{8}$ Pr. Prof. Dumitru Stăniloae, Chipul lui Hristos în Biserica răsăriteană: Iisus Hristos Darul şi Cuvântul Suprem al lui Dumnezeu, în „Ortodoxia”, nr. 1, 1973, p. 9.

${ }^{9}$ Idem, Ortodoxia în fața unor fenomene actuale din creştinismul apusean, în „Ortodoxia”, nr 2, 1974, pp. 339-340.

${ }^{10}$ Drd. Arhim. Dometie Manolache, art. cit., p. 233.

${ }^{11}$ Nicolae, Mitropolitul Ardealului, Despre unele caracteristici ale moralei catolice, în „Studii de teologie morală”, Sibiu, 1969, p. 199.

${ }^{12}$ Drd. Arhim. Dometie Manolache, art. cit., p. 233.
} 
Nerespectarea acestui raport complementar a dus, pentru părintele Dometie, la relativizarea credinței şi fărâmițarea gândirii creştine în Occident, care nu a mai ținut cont de învățăturile Sfintei Tradiții, cum amintea un Sfântul Ioan Gură de Aur, care avertiza: „Cercetați ideile, nu numai cuvintele aşa cum sunt scrise, căci rămânând numai la cuvintele scrise şi neînțelegându-le numai pe ele, multe erori sunt posibile"(Omilia VII, P.G., XLVIII, 769). Cu alte cuvinte lumea creştină occidentală „nu s-a silit să vadă îmbinarea ce trebuie să existe intre trăire şi cunoaştere, între ceea ce se înțelege şi ceea ce a rămas mai presus de ințelegere in credință" ${ }^{13}$. Rezultatul se va vedea, în timp, într-o primă fază când s-a ajuns la apariția grupărilor emoționale excentrice de tipul mişcării hyppy care proclamau libertatea amorului liber şi a vieții naturale până la grupările revendicativ-social-religioase, precum mişcarea Iisus al revoluţiei. În faza a doua, în America, aceste mişcări emoționale, odată cu anul 1953 vor duce la apariția mişcării neo-penticotiste, ce apare, la inceput, în anglicanism şi prezbiteranism ... ca din anul 1960 să ajungă şi în mediile protestante din Franța şi Germania, iar din anul 1967 să inceapă să se infiltreze in cercurile catolice sub denumirea de mişcarea harismatică de înnoire ${ }^{14}$ a Bisericii. Părintele Dometie observă, cu acrivie, că cele două perspective protestantă şi respectiv catolică sunt diferite ca mod de abordare teologică: "în timp ce protestantismul caută să folosească aceste mişcări pentru relativizarea şi ducerea mai departe a conținutului credinței şi a deosebirilor dintre Biserici, catolicismul caută să le mențină în cadrul Bisericii şi al teologiei, deşi laicii catolici, care participă la reunirea acestor mişcări, nu mai prea vor să țină cont de deosebirile confesionale, ci se contaminează de relativismul protestant" ${ }^{\prime 1}$. Urmarea se vede în comportamentul practic religios al „membrilor acestor grupări, care îşi vor dezvolta, autonom, un dispreț pentru

\footnotetext{
${ }^{13}$ Ibidem, p. 232.

${ }^{14}$ Ibidem, p. 233.

${ }^{15}$ Ibidem.
} 
structura Bisericii, pentru doctrină, având o afectivitate religioasă lipsită de o bază doctrinară temeinică ${ }^{\prime 16}$, ce a dus la apariţia credincioşilor lui Hristos, fără de instituția Bisericii.

\section{2. Dogmă şi trăire în creştinismul Răsăritean şi cel Occidental}

Cum de s-a ajuns aici? După o profundă meditație, părintele Dometie ajunge la concluzia că abordarea insuficientă şi reducționistă a dogmei, ce nu mai este văzută dintr-o triplă perspectivă a sentimentului, voinței şi a raţiunii, este piatra de poticnire în lumea creștină occidentală, atât catolică, cât şi protestantă. Dacă în Biserica romano-catolică, înainte de 1054 exista o teologie a dogmelor mai mult sau mai puţin comună cu Răsăritul ortodox, după această dată, prin intermediul papei, văzut ca un alter altar Hristos, ei vor formula noi dogme care nu sunt descoperite nici trăite de ambianța Bisericii ecumenice şi a prelungirii ei în Biserica ortodoxa ${ }^{17}$. Formularea de noi dogme, în catolicism, va porni de la afirmarea generală a unei pluralității în gândirea sistemică doctrinară, datorită libertății de manifestare a Duhului, ce va implica, potrivit lor, un pluralism dogmatic care va fi greu de distins de relativism ${ }^{18}$. Pentru Ortodoxie, însă, dogma este neschimbătoare, deşi în evoluția ei, până la promulgarea ei, nu se exclude şi un progres al acesteia, prin dezbaterile asupra înțelegerii Adevărului divin ${ }^{19}$. Făcând apel la gândirea Sfântului Grigorie de Nissa, pentru a scoate în evidență devierile dogmatice romano-catolice, părintele Dometie amintea apologetic că acest mare scriitor al secolului IV scria: „Nu cu ideea de hrană ne hrănim, ci cu hrana însăşi ... care este Hristos Cel Viu, descoperit în Euharistia Sfintei Liturghii”, cu alte cuvinte, prin extrapolare, nu cu dogmele ex-catedra promulgate de papă în fața altarului de la Roma ${ }^{20}$. Mai mult, gândirea catolică, accentuând

\footnotetext{
${ }^{16}$ Ibidem.

17 Ibidem.

${ }^{18}$ Ibidem.

19 Ibidem.

${ }^{20}$ Ibidem.
} 
unilateral reducţionist, în funcție de timp, sentimentul, voinţa şi rațiunea omului se va „centra pe o spiritualitate dincolo de definițiile dogmatice sinodale, numai pe o comunicare afectivă la un moment dat, ce nu-şi găseşte temei din punct de vedere ortodox, aceasta fiind văzută ca religia desăvârşită, ea adresându-se atât gândirii, inimii, voinței, imaginației cât şi tuturor puterilor omului deopotrivă ${ }^{21}$. Pe acelaşi ton, părintele Dometie aminteşte că Ortodoxia, spre deosebire de gândirea catolică, nu şi-a convertit şi epuizat dogmele în sisteme teologice ... pe care să le opună ca pe nişte explicații totale şi exclusive ale realității, altor sisteme filozofice şi ştiințifice. Ea a fost, este şi va fi activă, gata oricând pentru orice jertfă în slujba iubirii de Dumnezeu şi de oameni ${ }^{22}$. Apusul catolic, prin dorinţa lui de a restabili comuniunea dreptei credințe prin accentuarea unilaterală a trăirii credinței efective, după care se vor inspira multele denominațiuni protestante, ce vor căuta să scape de chingile orgoliului speculaţiei teologice, crezând că pot vedea, in trăirea lor subiectivă, punctele esențiale ale credinței creştine. În acest context, mişcările neo-penticoste, în viziunea lor luciferică, vor crede că prin depăşirea planurilor definițiilor (dogmatice s.n.), pot realiza adevărata unitatea creştină, ce nu se poate realiza datorită bisericilor istorice care rămân ancorate în definițiile lor de credința $^{23}$. In faţa acestei provocări, Ortodoxia, deşi a fost ferită de astfel de mişcări extremiste, caută să-şi protejeze tezaurul învățăturii sale şi căldura duhovnicească pe care şi-o trage din dogmele ei de credință, comunicată într-o viață liturgică bine definită, prin slujbele şi scrierile duhovniceşti patristice, atât de mult prețuite şi citite. Pentru credința Răsăriteană, dogmele nu au fost şi nu vor deveni definiții reci intelectuale, opinii particulare cu dispute speculative, $c i$ au rămas şi vor rămâne izvoare de viață afectivă metanoică din

\footnotetext{
${ }^{21}$ Ibidem, p. 234.

${ }^{22}$ Ibidem.

${ }^{23}$ Ibidem.
} 
unicitatea Sfintei Treimi ${ }^{24}$. Pentru creştinul ortodox, scrie părintele Dometie, cunoaşterea şi unirea credinciosului cu Dumnezeu nu constă, de aceea, numai în credință, ci şi în împlinirea voii şi poruncilor lui Dumnezeu prin iubirea jertfelnică dintre Eu-Tu-El. Acesta este sensul luminii cunoaşterii şi al trăirii dogmelor în Ortodoxie ${ }^{25}$.

3. 3. Nevoia naturală a credinciosului de a pătrunde adâncul revelat al dogmei atât sub aspectul cunoaşterii, cât şi al trăirii lui

Istoria disputelor dogmatice, din punct de vedere duhovnicesc, apare ca o grijă statornică a Bisericii, de a păstra, posibilitatea ințelegerii corecte a adevărurilor dogmatice, atât sub aspectul cunoaşterii cât şi al trăirii afective pentru nevoile credincioşilor ${ }^{26}$. Făcând apel la Sfântul Maxim Mărturisitorul, care vede în iubire cea mai înaltă formă de cunoaştere, părintele Dometie amintea cuvintele acestuia: cu cât cunoaşte cineva mai mult pe Dumnezeu, cu atât îl iubesste mai mult, cu cât îl iubeşte mai mult, cu atât îl cunoaşte mai $m u l t^{27}$. Cunoaşterea şi iubirea se împletesc armonios, din această perspectivă în Ortodoxie, ele culminând prin trăirea învățăturilor de credință dogmatice. Întreaga misiune a Mântuitorului a fost, nu numai, de a fi Învățător de Adevăr, ci şi Cale de viață, concretizată în iubirea citirii cuprinsului Sfintelor Evanghelii şi a epistolelor apostolice, prin Sfintele slujbe, dar şi a cunoaşterii, pătrunderii şi trăirii adevărurilor revelate, datorită mărturiei garantate de prezența Sfântului Duh din şi în Biserică ${ }^{28}$. Intre dogma mărturisită de Biserică şi între roadele Bisericii pe care ea le produce în sufletele credincioşilor, scrie părintele Dometie, este o legătură atât de mare,

\footnotetext{
${ }^{24}$ Pr. Prof Mihai Bulacu, Cunoaşterea lui Dumnezeu prin Ortodoxie, în „Glasul Bisericii”, nr.9-10, 1973, p. 1054.

${ }^{25}$ Drd. Arhim. Dometie Manolache, art. cit., p. 234.

${ }^{26}$ Ibidem, p. 235.

27 Alexandru Augustin Bidean, Adevăr şi trăire religioasă, în „Studii Teologice", nr. 7-8, 1973, p. 512.

${ }^{28}$ Ibidem.
} 
încât, nici unuia dintre credincioşii Bisericii Ortodoxe nu i-a trecut, de aceea, prin gând să despartă Învățătura de Viață, Învățătura fără viață fiind ca mişcarea curelei pe o roată scoasă din angrenajul maşinii, iar viață fără învățătură fiind ca frunza sau ca nisipul în furtuna ${ }^{29}$. Ținând cont de aceste nevoi ale credincioşilor, Biserica, sublinează părintele Dometie, a adăugat, cu timpul, noi mijloace de a face mai concrete şi mai simțite de inimă adevărurile revelate, prin iconografie, prin măreția slujbelor bisericeşti, în care $s-a$ inveşmântat misterul liturgic, pentru ca astfel, pe cale intuitivă să se treacă de la înțelegerea armoniilor universului creat, la frumusețea lumii necreate. $\mathrm{Cu}$ alte cuvinte, dogma a devenit o cunoaştere trăită $\breve{~}^{30}$.

În Occident, datorită separației dintre iubire şi cunoaştere, scrie părintele, s-a ajuns ca unii teologi să pună când dragostea mai sus, când cunoaşterea rațiunii, de unde apariția atâtor mişcări şi grupări religioase. Pentru el răspunsul Ortodoxiei nu este o simplă cunoaştere speculativă teoretică, ci e vorba de ceva mult mai adânc şi cuprinzător, este vorba de posesiunea totală a lui Dumnezeu ${ }^{31}$. Cunoaşterea şi trăirea sănătoasă a adevărurilor revelate prin dogme ajută la adâncirea progresivă a înțelesului lor depăşind unilateralismul cunoaşterii fără iubire şi a iubirii fără cunoaştere sau a formalismului fals şi sec. Pentru Biserica ortodoxă, scrie părintele Dometie, de aceea, nu există alt mod de mântuire decât cel asigurat de trăirea cu Hristos în Biserică, conform normelor exprimate de dogme ... cine se abate de la normele dogmatice se abate de la calea mântuirii, se abate de la esența adevăratei evlavii care constă din Invățătura Dreaptă şi faptele bune ${ }^{32}$.

${ }^{29}$ Prof. Nicolae Chițescu, Condițiile însuşirii mântuirii, în „Studii Teologice”, nr. 1-2, 1950, p. 17.

${ }^{30}$ Drd. Arhim. Dometie Manolache, art. cit., p. 236.

${ }^{31}$ Ibidem.

${ }^{32}$ Dumitru Stăniloae, Noțiunea dogmei, în „Studii teologice”, nr. 9-10, 1964, p. 540 . 
3. 4. Mijloacele de valorificare şi de trăire efectivă a dogmelor în viața credincioşilor ortodocşi

A. Comuniunea credincioşilor. Punerea în practică a adevărurilor revelate a dogmelor, înseamnă colaborarea integrală a tuturor funcțiunilor sufleteşti de la gândire, sentiment, voință, toate fiind unite prin puterea iubirii jertfelnice in comuniunea credincioşilor, pe de o parte, intre credincioşi şi preot şi a tuturor cu Dumnezeu, care este treapta cea mai înaltă a comunității creștine $e^{33}$. Trăirea dimensiunii cunoaşterii şi a iubirii Unicului Adevăr va duce la adevărata fericire a credinciosului, ea nerealizându-se decât în duhul de comuniune al credincioşilor, care devin frați unii cu alții în credință, iar pe de altă parte frați cu păstorul lor, preotul ortodox: numai în comuniunea largă a întregii Biserici sau parohii se activează dragostea creştină. Numai în ea se îmbogățeşte şi se intăreşte fiecare creştin cu darurile şi experiențele celorlalț ${ }^{34}$ dar şi cu darurile oferite de Dumnezeu prin intermediul preotului în cadrul sfintelor slujbe. Astfel răspunsurile ce se dau în comun în timpul slujbelor, împărtăşirea din acelaşi Sfânt Potir cu preotul, dialogul de suflet din cadrul Sfintei Spovedanii, precum şi celelalte Sfinte Taine şi ierurgii, conduc la o comuniune de simțire comunitară deplină. Aceasta pentru că cultul ortodox, în structura lui, cuprinde momente şi acțiuni de cea mai înaltă tensiune sufletească ce uneşte cerul cu pământul ... această comuniune afectivă cuprinzându-i, inclusiv, pe cei repausați prin cultul Sfinților şi rugăciunile pentru morți ce țin vie afecțiunea şi responsabilitatea nu numai între cei vii ... ci şi între ei sii cei ce au fost inainte ${ }^{35}$.

B. Sfânta Liturghie. Ca şi mijloc de pastorație, Sfânta Liturghie nu este o slujba ca oricare alta, ci Slujba Slujbelor, ea adresându-se tuturor funcțiunilor sufleteşti ale credincioşilor şi demonstrând, în fapt, că în Răsărit verbul a învăța capătă sensul de a edifica: esența

\footnotetext{
${ }^{33}$ Drd. Arhim. Dometie Manolache, art. cit., p. 237.

${ }^{34}$ Ibidem.

${ }^{35}$ Ibidem.
} 
gândirii şi trăirii profund ortodoxe, poate fi înțeleasă numai aici, când credinciosul vede desfăşurându-se, în chip tainic, dar real, intreaga lucrare de mântuire a Domnului Iisus Hristos prin momente şi acțiuni de cea mai înaltă tensiune sufletească, prin drama ce se desfăşoară de-a lungul celor două părți constitutive ale acesteia ${ }^{36}$. Ca pentru toți slujitorii Bisericii, pentru părintele Dometie, Jertfa de pe Cruce a Mântuitorului a fost centrul activității Sale Răscumpărătoare şi totodată faptul cel mai de seamă din istoria mântuirii lumii, prin Sfânta Liturghie actualizându-se această Jertfă ... care este pusă în miezul întregului cult ortodox ${ }^{37}$. Prin Sfânta Liturghie, lumea cerească se lasă în jos în întunecimea lumii ... Dumnezeu întorcându-se prin Slujba Slujbelor, în sufletul omului pe care îl sfințeşte, îl transfigurează şi îl îndumnezeieşte ${ }^{38}$. Voind să redea, în cuvinte omeneşti, acest proces de înaltă simțire duhovnicească, părintele Dometie va apela la cuvintele Sfântului Maxim Mărturisitorul care exclama: „Vino Cuvinte al lui Dumnezeu, vrednic de laudă; dă-ne revelația cuvintelor Tale pe măsura puterilor noastre şi ridicând grosimea vălului, arată-ne Hristoase, frumusețea lucrurilor inteligibile" ${ }^{39}$. Astfel, pentru părintele Dometie Sfânta Liturghie a fost şi este cel mai de seamă mijloc de valorificare şi de trăire efectivă a dogmelor: ea a trăit dogmele în slujbele bisericeşti şi dogmatica obişnuită a fost Sfânta Liturghie ${ }^{40}$.

C. Sfintele Taine şi ierurgiile. Transfigurarea lumii, ce are ca scop final mântuirea, este pentru părintele Dometie un proces teandric, un act în care Dumnezeu şi omul credincios colaborează, Sfintele Taine şi ierurgiile fiind semnul văzut al acestei colaborări, în care Dumnezeu dă Harul său, iar cel ce crede îl primeşte ${ }^{41}$. În acest

\footnotetext{
${ }^{36}$ Ibidem.

${ }^{37}$ Ene Branişte, Liturghia Ortodoxă(manuscris), fascicola IV, p. 367.

${ }^{38}$ Drd. Arhim. Dometie Manolache, art. cit., p. 238.

${ }^{39}$ Drd Ieromonah Veniamin Micle, Cuvântul lui Dumnezeu şi Sfintele Taine în Biserica Ortodoxă, în „Ortodoxia”, 1972, pp. 553-554.

${ }^{40}$ Prof. Nicolae Chițescu, art. cit., p. 17.

${ }^{41}$ Drd. Arhim. Dometie Manolache, art. cit., p. 239.
} 
context, toate Tainele nu trebuie să fie socotite, aminteşte părintele Dometie, cuvinte şi ceremonii magice, ci o expresie a credinței Bisericii prin care ea impărtăşeşte şi-şi propune să împărtăşească harul special al fiecărei Taine ${ }^{42}$. Astfel, Biserica va fi prezentă, în toate actele din viaţa credincioşilor, prin lucrările şi acţiunile harice, ea binecuvântând şi sfinţind, încurajând, mângâind şi tămăduind bolile trupeşti şi sufleteşti ale credincioşilor. Sfintele Taine sunt mijloace puternice de valorificare şi de trăire afectivă a dogmelor. Primele Taine - Botezul, Mirungerea şi Sfinta Împărtăşanie - oferă, celui care le primeşte, tot ceea ce este necesar pentru dezvoltarea vieții, pentru sănătatea sufletului şi a trupului şi dobândirii vieții veşnice. Ele dau puterea pentru tot drumul duhovnicesc ... dacă actualizează această putere a veşniciei prin eforturi conştiente, adică pentru cele trei stadii ale acestui drum: curățirea, luminarea şi desăvârşirea ${ }^{43}$. Astfel, prin prima Taină, cea a Botezului, cel afundat în apă se renaşte spiritual ... fiind altoit în butucul viei care este Hristos şi devenind mlădiţă ce se hrăneşte din sevele vieții Lui divine, după Chipul lui Hristos. În conformitate cu învăţătura Bisericii, părintele Dometie aminteşte că dacă Botezul este taina naşterii din nou, mirungerea este Taina creşterii în viața spirituală, prin care cel botezat primeşte darurile Sfântului Duh, spre creştere şi sporire, în viața cea nouă de trăire cu Iisus Hristos ${ }^{44}$. Cuminecătura, care se dă ulterior după Sfântul Botez, va deveni hrana Vieții celei noi, după cuvintele Domnului: „Cel ce mănâncă Trupul meu şi bea sângele Meu, petrece întru Mine şi Eu întru el'(Ioan 6, 56). Hrana vieții celei noi, însă, îl uneşte pe noul botezat nu numai cu Hristos, ci ... cu cei mulți ajungând un trup - că toți ne împărtăşim dintr-o Pâine (I Cor. 10,17), ea devenind Taina unității tuturor credincioşilor. Sfânta Taină a spovedaniei împărtăşeşte primitorului ei, harul iertării păcatelor săvârşite după Botez şi împăcarea cu Dumnezeu. Ea este socotită, de părintele Dometie, ca Taina minunatei pedagogii divine

\footnotetext{
42 Ibidem.

43 Nicolae, Mitropolitul Ardealului, Valoarea morală a Sfintelor Taine, în „Studii de teologie morală”, Sibiu, 1969, p. 280.

${ }^{44}$ Drd. Arhim. Dometie Manolache, art. cit., p. 239.
} 
... o convorbire dintre duhovnic şi penitent, o necesitate spirituală pentru credinciosul de azi, ca şi pentru cel din trecut ${ }^{45}$. Taina Sfântului Maslu, prin puterea Harului dumnezeiesc, se revarsă pentru vindecarea celui bolnav, cât şi pentru iertarea păcatelor lui. Prin Taina Preoției şi Taina Nunţii, prin rosturile speciale puse în slujba comunității, sunt pline de trăirea adevărurilor dogmatice. Prin a doua se întemeiază familia creştină, ce stă la temelia multor virtuți creştine, iar prin prima se consfințeşte nunta duhovnicească, prin care preotul sau episcopul devine mire al parohiei sau eparhiei sale care îi este mireasă. Ierurgiile sunt şi ele un mijloc puternic de valorificare şi de trăire a dogmelor, prin ele credincioşii dobândind noi puteri morale, de înnoire duhovnicească, de luptă împotriva păcatului şi de propăşire în virtute.

D. Cântări şi citiri din scrierile bisericeşti şi filocalice. În Biserica Ortodoxă, scrie părintele Dometie, acestea sunt adecvate realităților trupeşti şi sufleteşti ale credinciosului. Prin psalmodiere sau tovărăşia laolaltă a glasului ${ }^{46}$, credincioşii sunt adunați laolaltă, într-un singur glas de cor pentru cele 7 Laude bisericeşti, ele fiind cele mai rodnice mijloace de apărare în fața atacurilor celor ce vor să facă prozeliți din rândurile ortodocşilor. În Biserica strămoşească, Laudele, cântările şi imnele acatiste sunt alcătuite pe bază de dogme, nu prin cântări în afară de dogme $e^{47}$.

E. Rugăciunea de obşte şi particulară. Modul cel mai sublim al adevărurile dogmatice, şi-1 manifestă credinciosul, însă, prin rugăciune care este ridicarea minții şi voii noastre către Dumnezeu ... cel ce iubeşte pe Dumnezeu de-a pururi stă de vorbă cu El, cum stă cu un tată ce alungă orice gând pătimaş ${ }^{48}$. În acest dialog, cea mai de seamă roadă a rugăciunii este dumnezeiasca dragoste, care nu este din lumea aceasta. Împropriindu-şi cuvintele Sfântului Simeon Noul Teolog, părintele Dometie exclamă împreună cu acesta laudativ „O,

\footnotetext{
${ }^{45}$ Nicolae, Mitropolitul Ardealului, art. cit., p. 280.

${ }^{46}$ Drd. Arhim. Dometie Manolache, art. cit., p. 240.

${ }^{47}$ Ibidem.

${ }^{48}$ Ibidem .
} 
Sfântă dragoste, cel ce nu te cunoaşte nu a putut gusta dulceața facerilor tale de bine pe care numai experiența trăită ne-o descoperă, căci Tu eşti împlinirea Legii ... puterea mucenicilor, insuflătorul părinților şi desăvârşirea tuturor sfinților"(Omilia LIII, 2).

\section{Concluzii}

Din lucrarea expusă în cadrul cursurilor de doctorat, părintele Dometie va trage trei concluzii importante:

1. În Biserica Răsăriteană există o mulțime de mijloace de valorificare şi de trăire afectivă a dogmelor în viaţa credincioşilor, începând de la Sfânta Liturghie şi terminând cu rugăciunea de obşte şi particulară.

2. Biserica Ortodoxă este împotriva elementului religios trăit în afara cadrului dogmelor şi cunoaşterii adevărate, mântuirea subiectivă neputându-se lăsa pe seama diferitelor emoții ale credinciosului, de unde cheia pastorației individuale este limpezirea ortodoxă a problemelor pe care le ridică religia subiectivă şi formația religioasă personală a ortodocşilor.

3. Pentru învățătura ortodoxă, trăirea religioasă subiectivă, va cuprinde credinciosul în întreaga sa unitate psihico-fizică, păstrarea echilibrului între emoțiile inimii şi viziunea integrală a credinței ducând la trăirea sănătoasă a credinței, prin valorificarea desăvârşită a adevărurilor revelate din dogme.

\section{Bibliografie}

1. Biblia sau Sfânta Scriptură, Bucureşti, Editura Institutului Biblic şi de Misiune al Bisericii Ortodoxe Române, 2004.

2. Bidean, Alexandru Augustin, Adevăr şi trăire religioasă, în „Studii Teologice", nr. 7-8, 1973, p. 512.

3. Branişte, Ene, Liturghia Ortodoxă (manuscris), fascicola IV.

4. Bulacu, Mihai, Cunoaşterea lui Dumnezeu prin Ortodoxie, în „Glasul Bisericii”, nr. 9-10, 1973, p. 1054. 
5. Chițescu, Nicolae, Condițiile însuşirii mântuirii, în „Studii Teologice”, nr. 1-2, 1950, p. 17.

6. Idem, Dogma şi viața creştină, în „Studii teologice”, nr. 1-2, 1954, p. 47.

7. Lumină Lină, Părintele Dometie, Cuvânt înainte IPS Antonie, Mitropolitul Ardealului, ed Ararat, Bulevardul Carol I, nr. 43, Bucureşti,

8. Manolache, Dometie, Dogmele şi valorificarea lor în viața credincioşilor ortodoç̧i, în „Studii Teologice”, nr. 3-4, martie-aprilie, 1975, pp. 232-240.

9. Manolache, Stelian, Jertfa euharistică a Bisericii oglindită în viața pilduitor-mărturisitoare a părintelui Dometie de la Râmeț, apărută în „Eucharist and Martyrdom from the Ancient Catacombs to the Communist Prisons, 6-8 mai 2014", vol. 2, Alba-Iulia, Edit. Reîntregirea, 2014.

10. Micle, Veniamin, Cuvântul lui Dumnezeu şi Sfintele Taine în Biserica Ortodoxă, în „Ortodoxia”, 1972, pp. 553-554.

11. Nicolae, Mitropolitul Ardealului, Despre unele caracteristici ale moralei catolice, în „Studii de teologie morală”, Sibiu, 1969; p. 199.

12. Nicolae, Mitropolitul Ardealului, Valoarea morală a Sfintelor Taine, în „Studii de teologie morală”, Sibiu, 1969, p. 280.

13. Pavel, Constantin C., Preocupări actuale în domeniul teologiei morale creştine, în „Studii Teologice”, nr. 3-4, 1973, p. 77.

14. Plămădeală, Antonie, Hans Kung şi declarația Mysterium Ecclesiae, Bucureşti, 1974.

15. Sf. Ioan Gură de Aur, Omilia a VIII a, în P.G. XLVIII, 769.

16. Stăniloae, Dumitru, Chipul lui Hristos în Biserica răsăriteană: Iisus Hristos Darul şi Cuvântul Suprem al lui Dumnezeu, în „Ortodoxia”, nr. 1, 1973, p. 9.

17. Stăniloae, Dumitru, Ortodoxia în fața unor fenomene actuale din creştinismul apusean, în „Ortodoxia”, 1974, nr. 2, pp. 339-340.

18. Stăniloae, Dumitru, Spiritualizarea structurilor Bisericeşti în epoca actuală şi cauzele ei, în „Ortodoxia”, 1972, nr. 4, pp. 521-522. 